Gut, 1981, 22, 237-241

Case report

\title{
Diffuse enterochromaffin-like (ECL) cell hyperplasia and multiple gastric carcinoids: a complication of pernicious anaemia
}

\author{
J R HODGES*, P ISAACSON, AND RALPH WRIGHT \\ From The Professorial Units of Medicine and Pathology, Southampton General Hospital, Southampton
}

SUMMARY A man with long-standing pernicious anaemia developed multiple gastric carcinoid tumours with a background of diffuse enterochromaffin-like cell hyperplasia. There is evidence that enterochromaffin-like cells synthesise and store histamine and that their proliferation is stimulated by high serum gastrin levels. Gastric carcinoid tumours can be difficult to differentiate from the more common adenocarcinomas and may be a more frequent complication of pernicious anaemia than is currently recognised.

Carcinoid tumours of the stomach are rare and account for $4-5 \%$ of all gastrointestinal tract carcinoids. ${ }^{2}$ They are seldom associated with the carcinoid syndrome ${ }^{3}$ and present with pain, bleeding, or anaemia. They usually appear as polypoid lesions and are located submucosally, making preoperative diagnosis by endoscopic biopsy difficult and unusual. ${ }^{4-6}$ Gastric carcinoids may be multiple, and Pestana et al. ${ }^{7}$ found six examples in 90 recorded cases; since then another seven patients with multiple tumours have been reported. ${ }^{5-12}$

Carcinoid tumours are of neuroendocrine tell origin and in the stomach arise from enterochromaffin (EC) or enterochromaffin-like (ECL) cells, the latter comprising the major endocrine cell type in the body of the stomach. ${ }^{13}$ The neuroendocrine cells in the body of the stomach have been shown to proliferate in patients with pernicious anaemias ${ }^{13-16}$ and chronic atrophic gastritis with achlorhydria. ${ }^{17}$

Review of the literature reveals 14 cases with gastric carcinoid tumours and pernicious anaemia or achlorhydria. ${ }^{467101218-44}$ Hyperplasia of the neuroendocrine cells in the non-tumorous mucosa has not been noted in these cases, although Black and $\mathrm{Haffner}^{8}$ have reported a patient with diffuse

*Address for correspondence and reprint requests: Dr J R Hodges, Professorial Medical Unit, Level D, S. Laboratory and Pathology Block, Southampton General Hospital, Southampton, SO9 4XY.

Received for publication 28 October 1980 hyperplasia of gastric argyrophil cells and multiple gastric carcinoids.

We report a patient with long-standing pernicious anaemia, multiple invasive gastric carcinoid tumours, and diffuse ECL cell hyperplasia.

\section{Case history}

A 47 year old man presented with a three month history of sweating attacks associated with facial flushing; each attack lasted 10 minutes and was not precipitated by food, alcohol, or activity. His weight remained steady and his appetite good. He suffered from psoriasis and long-standing seropositive deforming rheumatoid arthritis.

In 1951, at the age of 21 years, he was diagnosed as having pernicious anaemia, and since then had received regular injections of vitamin $\mathrm{B} 12$; this diagnosis was confirmed by the findings of a Schilling's test demonstrating intrinsic factor deficiency, a pentagastrin fast achlorhydria, and the presence of gastric parietal cell antibodies in the serum.

Examination revealed a pale, well-nourished man with rheumatoid deformity of the hands, rheumatoid nodules and psoriasis. The liver was enlarged $4 \mathrm{~cm}$, regular and soft, the spleen was just palpable. The remainder of the examination was entirely normal.

Investigations showed: haemoglobin $11 \cdot 2 \mathrm{~g} / \mathrm{dl}$ with a microcytic hypochromic blood film; ESR $117 \mathrm{~mm} / \mathrm{h}$. Liver function tests, isotopic and ultra- 
sound scanning of the liver, and liver biopsy were normal. At gastroscopy the stomach appeared atrophic with several small yellow sessile polypoid lesions approximately $1 \mathrm{~cm}$ in diameter high on the posterior wall. Multiple biopsies of these lesions and of the normal mucosa were taken. Histological examination showed chronic atrophic gastritis and the presence of a carcinoid tumour with invasion of muscularis mucosae (Fig. 1). Urine 5-hydroxyindol acetic acid (HIAA) estimation was normal on two occasions. Serum gastrin levels were grossly raised at 2520 and $2500 \mathrm{pg} / \mathrm{ml}$ (normal $52-84 \mathrm{pg} / \mathrm{ml}$ ). Calcitonin levels were normal. Serum pancreatic polypeptide, vasoactive intestinal peptide, calcitonin, growth hormone, and prolactin levels were normal.

At laparotomy the stomach appeared externally to be normal. There was no evidence of metastatic disease and the remainder of the viscera were normal. A total gastrectomy with oesophagojejunal anastomosis was performed. Postoperatively there were no complications and the patient was discharged well on the fourteenth day. He has been closely observed in outpatients and remains entirely asymptomatic with no evidence of tumour recurrence at 18 months.

\section{PATHOLOGY}

The gastrectomy specimen was characterised by the presence of congested finely granular mucosa in the body of the stomach, with virtual absence of rugal

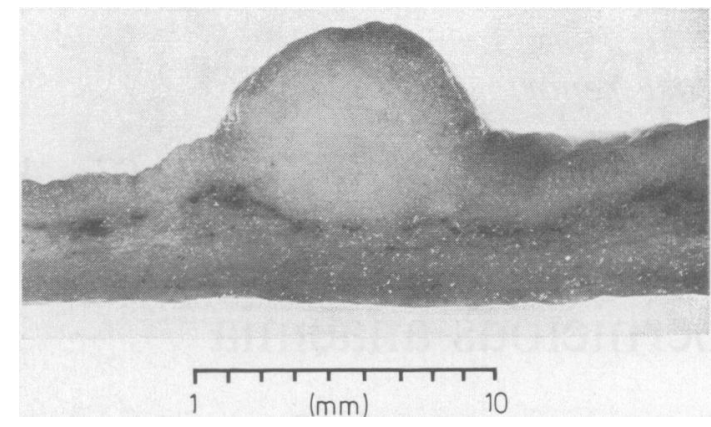

Fig. 2 Macroscopic appearance of a sagittal section through one of the tumours in the gastrectomy specimen. The tumour has invaded the submucosa.

folds. Six separate sessile tumours, the largest of which was $8 \mathrm{~mm}$ in diameter, were identified (Fig. 1). Histologically, these were identical with the carcinoid tumour in one biopsy (Fig. 2) consisting of nests of small round cells showing little pleomorphism but with occasional acinus formation. Grimelius staining revealed abundant argyrophil granules in the tumour cells (Fig. 3). Sections of gastric mucosa between the tumours (Fig. 4) showed chronic atrophic gastritis with intestinal metaplasia without the presence of parietal cells. Small nests of argyrophil-positive cells, similar to those in the tumour, were present throughout the mucosa, sometimes extending into the muscularis mucosae.

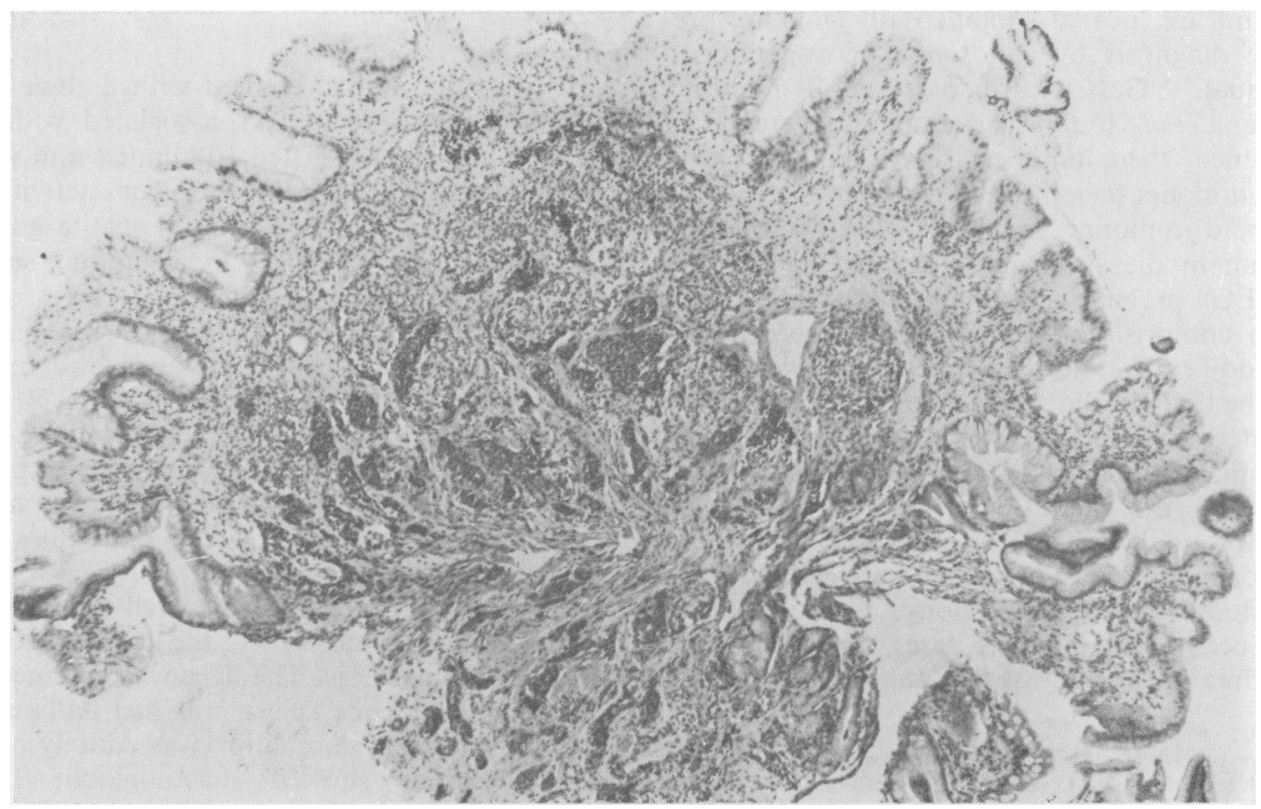

Fig. 1 Endoscopic gastric biopsy showing a carcinoid tumour infiltrating the lower lamina propria and muscularis mucosae. $H$ and $E, \times 40$. 
Electron microscopy (Fig. 5) showed numerous small secretory granules within tumour cells. Many of these showed a halo between the granule and the limiting membrane. These granules resembled those seen in ECL cells of normal gastric mucosa.

\section{Discussion}

Increased numbers of neuroendocrine cells have been observed in the gastric mucosa of patients with pernicious anaemia. Study of these proliferated cells in non-intestinalised epithelium of the body of the stomach has shown them to be principally ECL cells. ${ }^{1316}$ The classification of the cell type has been disputed by other workers, who claim that they are of $\mathrm{G}$ cell type, ${ }^{15}$ although the latter cells are not found in normal gastric body mucosa.

Patients with pernicious anaemia have markedly raised serum gastrin levels. ${ }^{25}$ Raised serum gastrin levels are also found in patients with chronic atrophic

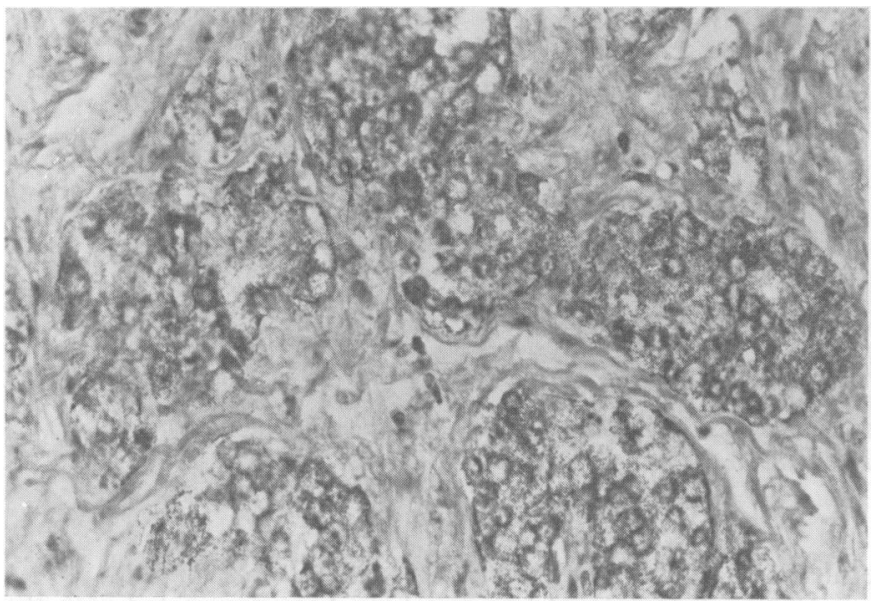

Fig. 3 Detail of carcinoid tumour showing argyrophil granules in the tumour cells. Grimelius, $\times 200$.

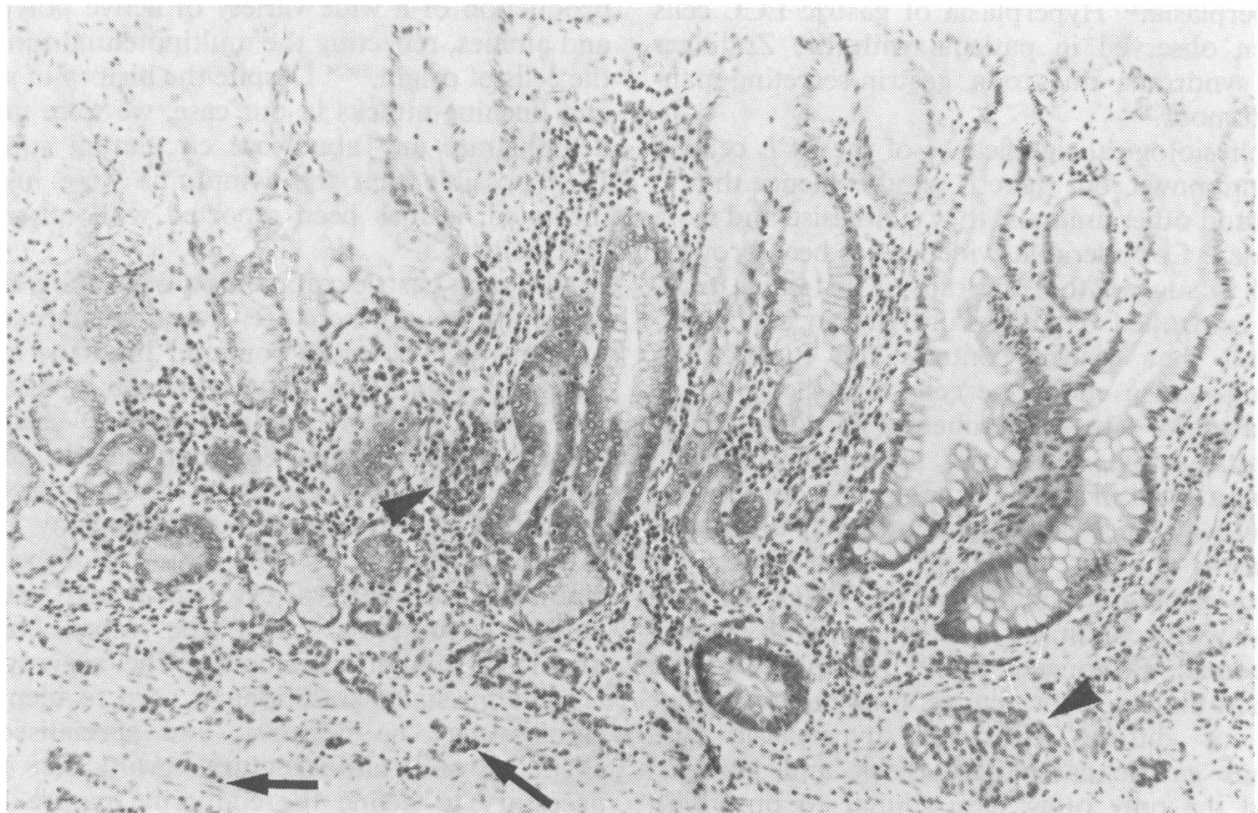

Fig. 4 'Uninvolved' mucosa from gastrectomy specimen, showing chronic atrophic gastritis with intestinal metaplasia. Small nests of cells, similar to those in the carcinoid tumours, are present in the mucosa (arrow heads) and muscularis mucosae (arrows). $H$ and $E, \times 100$. 


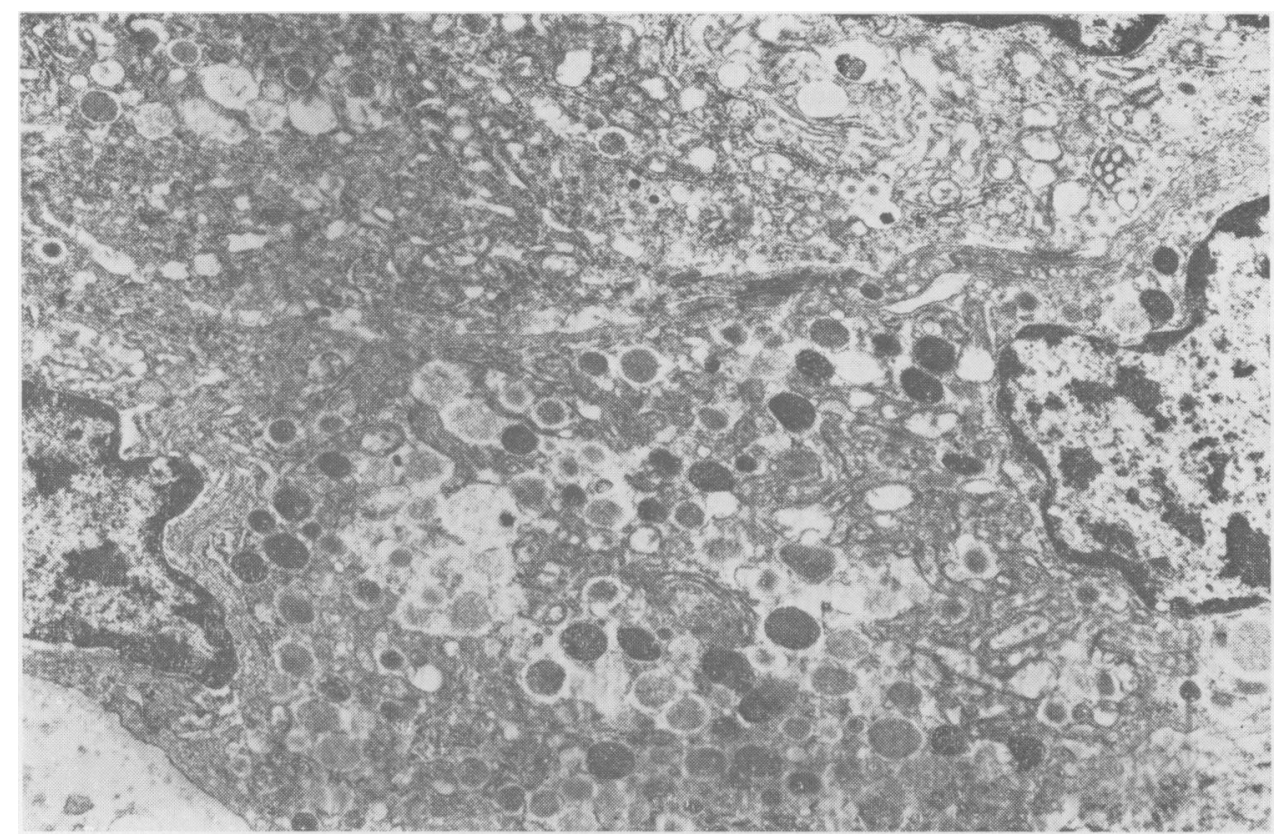

Fig. 5 Electron-micrograph of a carcinoid tumour, showing characteristic secretory granules with surrounding haloes. $\times 10,800$.

gastritis and achlorhydria without pernicious anaemia ${ }^{26}{ }^{27}$ who have also been shown to have ECL cell hyperplasia. ${ }^{17}$ Hyperplasia of gastric ECL cells has been observed in patients with the Zollinger Ellison syndrome due to a gastrin-secreting pancreatic tumour. ${ }^{28}$

The physiological significance of the ECL cells in man is unknown, but there is good evidence that in the rat (and other animals) they synthesise and store histamine. ${ }^{29}$ Considerable evidence has been brought forward to suggest that the rate of histamine turnover is controlled by the serum gastrin concentration, and that gastrin controls the function of histamine-storing endocrine cells and their rate of proliferation. ${ }^{29}$ The experimental production of hypergastrinaemia in the rat by antral exclusion results in a great increase in the number and size of ECL cells in the gastric mucosa. ${ }^{30}$ If the same mechanisms apply in man, this would explain the observed proliferation of gastric ECL cells in patients with conditions associated with hypergastrinaemia. Prolonged ECL hyperplasia could precede frank neoplastic change, thus explaining our finding of diffuse ECL cell hyperplasia and numerous gastric carcinoids. Black and Haffner ${ }^{8}$ reported the only other case similar to ours with diffuse hyperplasia of the gastric argyrophil cells and mutiple carcinoids; their patient had no obvious cause for the cell proliferation, although serum gasirin levels were not available.

Carcinoid tumours have been associated with the production of a wide variety of active polypeptides and amines, reflecting the multipotential function of the cells of origin. ${ }^{1024}$ Despite the history of sweating and flushing attacks in our case, we were unable to demonstrate any abnormal circulating substances. It is possible that the symptoms were histaminemediated, as has been reported with other gastric carcinoids. ${ }^{31}$

Although gastric carcinoids are generally regarded as rare tumours, there are several reasons why they may, in fact, be more common than the literature suggests. There are only very subtle histological differences between undifferentiated gastric carcinoids and the more common gastric adenocarcinomas, and these differences are likely to be overlooked if the tumours are studied by ordinary histological means. ${ }^{22} 32$ The majority of gastric carcinoids exhibit atypical cytological and histological patterns, compared with the more commonly diagnosed midgut carcinoids. The argyrophil and argentaffin stains traditionally used to identify carcinoids may be negative, and specialised histochemical and ultrastructural evaluation may be necessary to define the endocrine nature of these tumours. ${ }^{32}$ In a recent study, Rogers and Murphy ${ }^{33}$ found 10 previously undiagnosed carcinoids in a series of 140 gastric carcinomas; the five year 
survival of the carcinoids was six times that of the gastric adenocarcinomas. Accurate identification of gastric carcinoids is thus more than a purely academic exercise. Because of the much more indolent course of even advanced carcinoids, aggressive surgical resection should be strongly considered.

We suggest that carcinoid tumours may account for a part of the reported increased incidence of gastric carcinomas in patients with pernicious anaemia. Careful inspection of the non-tumorous mucosa in these patients might reveal ECL cell hyperplasia arising as a consequence of longstanding hypergastrinaemia.

We are indebted to Dr S R Bloom, Hammersmith Hospital, London, for performing the hormone assays and to Dr Julia M Polak, Hammersmith Hospital, Royal Postgraduate Medical School, London, who confirmed the diagnosis of a gastric carcinoid of ECL cell origin.

\section{References}

${ }^{1}$ McDonald RA. A study of 356 carcinoids of the gastrointestinal tract. Am J Med 1956; 21 : 867-78.

${ }^{2}$ Hajdu SI, Winawer SJ, Myers WPL. Carcinoid tumours. Am J Clin Pathol 1974; 61: 521-8.

${ }^{3}$ Christodoulopoulos JB, Klotz AP. Carcinoid syndrome with primary carcinoid tumour of the stomach. Gastroenterology 1961 ; 40: 429-40.

'Lattes R, Grossi C. Carcinoid tumours of the stomach. Cancer 1956; 9: 698-711.

${ }^{5}$ Kornfield HR, Sherlock P, Hertz R. Multiple carcinoid tumours of the stomach with endoscopic observation. Gastrointest Endosc 1971; 18: 74-7.

'Gueller R, Haddad JK. Gastric carcinoids simulating benign polyps. Gastrointest Endosc 1975; 21 : 153-5.

'Pestana C, Beahrs OH, Woolner LB. Multiple (seven) carcinoids of the stomach: report of a case. Proc Mayo Clin 1963; 38: 453-6.

${ }^{8}$ Black WC, Haffner HE. Diffuse hyperplasia of gastric argyrophil cells and multiple carcinoid tumours. Cancer 1968; 21: 1080-99.

${ }^{\circ}$ Vaughan J, Delancey H. Multiple carcinoid tumours of stomach. South Med J 1973; 66: 728-9.

${ }^{10}$ Freisen SR, Hermreck AS, Mantz FA. Glucagon, gastrin and carcinoid tumors of the duodenum, pancreas and stomach: polypeptide 'apudomas' of the foregut. Am J Surg 1974; 127: 90-101.

${ }^{11}$ Seifert E, Elster K. Carcinoids of the stomach. Am J Gastroenterol 1977; 68: 372-78.

${ }^{12}$ Harris AI, Greenberg H. Pernicious anaemia and the development of carinoid tumours of the stomach. JAMA 1978; 239: 1160-1.
${ }^{13}$ Rubin W. Proliferation of endocrine-like (enterochromaffin) cells in atrophic gastric mucosa. Gastroenterology 1969; 57: 641-8.

${ }^{14}$ Polak JM, Coulling I, Doe W, Pearse AGE. The G cells in pernicious anaemia. Gut $1971 ; 12: 319-23$.

${ }^{15}$ Polak JM, Hoffbrand AV, Reed PI et al. Qualitative and quantitative studies of antral and fundic $\mathbf{G}$ cells in pernicious anaemia. Scand J Gastroenterol 1973; 8: 361-7.

${ }^{16}$ Rubin W. A fine structural characterisation of the proliferated endocrine cells in atrophic gastric mucosa. Am J Pathol 1973; 70: 109-18.

${ }^{17}$ Bordi C, Costa A, Missale G. ECL-cell proliferation and gastrin levels. Gastroenterology 1975; 68: 205-6.

${ }^{18}$ Lemmer KE. Carcinoid tumours of the stomach. Surgery 1942; 12: 378-82.

${ }^{19}$ Martin JD, Atkins EC. Carcinoid tumours of the stomach. Surgery 1952; 31: 698-704.

${ }^{20}$ Hines CR, Savage JL. Carcinoid tumours of the stomach Ann Intern Med 1955; 43: 859-67.

${ }^{21}$ Sheahan DG, Horowitz SA, Zamcheck N. Deletion of epithelial ABH isoantigens in primary gastric neoplasms and in metastatic cancer. Am J Dig Digs 1971; 16: 961-9.

${ }^{22}$ Soga J, Tazawa K, Aizawa $\mathrm{O}$ et al. Argentaffin cell adenocarcinoma of the stomach: an atypical carcinoid. Cancer 1971; 28: 999-1003.

${ }^{23}$ Bordi C, Senatore S, Missale G. Gastric carcinoid following gastrojejunostomy. Am J Dig Dis 1976; 21: 667-71.

${ }^{24}$ Bader LV, Lykke WJ, Hinterberger H. Multiple biogenic amine-secreting carcinoid tumour of the stomach: a case report. Pathology 1977; 9: 353-8.

${ }^{25}$ McGuigan JE, Trudeau WL. Serum gastrin concentrations in pernicious anaemia. $N$ Engl J Med 1970; 282: 358-61.

${ }^{26}$ Korman MG, Strickland RG, Hansky J. Serum gastrin in chronic gastritis. $\mathrm{Br}$ med $J 1971 ; 1$ : 16-8.

${ }^{27}$ Stockbrugger R, Angervall L, Lundquist G. Serum gastrin and atrophic gastritis in achlorhydric patients with and without pernicious anaemia. Scand J Gastroenterol 1976; 11 : 713-9.

${ }^{28}$ Bordi C, Cocconi G, Togni R et al. Gastric endocrine cell proliferation associated with Zollinger-Ellison syndrome. Arch Pathol 1974; 98: 274-8.

${ }^{29}$ Hakanson R, Sundler F. APUD cells in rat oxyntic mucosa. Gastroenterology 1979; 77: 800-3.

${ }^{30}$ Aluments J, El Munshid HA, Hakanson R et al. Effect of antral exclusion on endocrine cells of rat stomach. $J$ Physiol 1979; 286: 145-55.

${ }^{31}$ Hosoda S. Carcinoid tumours-review of literature with special reference to sites of origin and humoral substances produced. Acta Pathol Jpn 1972; 22: 533-40.

${ }^{32}$ Chejfec G, Gould VE. Malignant gastric neuroendocarcinomas. Hum Pathol 1977; 8: 433-40.

${ }^{33}$ Rogers LW, Murphy RC. Gastric carcinoid and gastric carcinoma, morphological correlates of survival. Am J Surg Pathol 1979; 3: 195-202. 